\title{
THE ROLE OF THE GENE POOL IN THE CONSERVATION OF BIOLOGICAL DIVERSITY
}

\author{
Farida Rabbimova
}

Lecturer Jizzakh State Pedagogical University, Uzbekistan

\section{ABSTRACT}

This article examines the importance of the Republic of Uzbekistan for the conservation of biodiversity. Uzbekistan is a relatively agrarian country and largely depends on the state of natural biological resources.

KEYWORDS: - Biodiversity, microorganism, ecotism, species, genetics, ecological gene pool, gegradation, gilobal, ratification, convention, strategy.

\section{INTRODUCTION}

What is biodiversity? The concepts of "biodiversity" is relatively new and not yet widely understood. The diversity of all life there means animals, plants, microorganisms, their genes and ecosystems. The term "biodiversity" refers not to statistical information about a particular organism, but to the interactions between all parts of the biological world. Most biodiversity is considered in three stages: 1 . Species diversity, i.e. the diversity of all animals and plants, including fungi and microorganisms; 2. Genetic diversity is the diversity of genetic material within a species; 3 . Ecotic diversity is the diversity of ecosystems (e.g., forests, mountains, steppes or savannas, deserts, etc.). Together, these levels form the components of biodiversity.

\section{THE MAIN FINDINGS AND RESULTS}

Biodiversity is an urgent and potential resource to meet the economic, environmental, cultural and aesthetic needs of society. Without it, the sustainable development of society is impossible. However, it is also recognized from scientific circles that the world is rapidly becoming more homogeneous in terms of gene pool, biological species and the ecotisms they form. This is due to human impact, primarily due to the rapid spread of modern models of supply, manufacturing, trade, agriculture and industrial development, housing construction, population growth around the world, human impact on biodiversity is growing rapidly.

The economic and ecological significance of biodiversity is not yet widely understood. In some cases, people are unable to adequately imagine the interdependence of biological species within an ecosystem and the impact of the loss of one species on another. As we enter the XXI century, slowing down biodiversity loss 
CURRENT RESEARCH JOURNAL OF HISTORY 2(6): 27-29, June 2021

DOI: https://doi.org/10.37547/history-crjh-02-06-06

ISSN 2767-472X

(C)2021 Master Journals

\section{Crossref dof 80 Google}

Accepted 11 ${ }^{\text {th }}$ June, 2021 \& Published $16^{\text {th } J u n e, ~} 2021$

and conserving waste is becoming a huge challenge.

Biodiversity is an important source of life for both the world community and each country. It underlies economic activity and finding a source of livelihood, and its preservation and efficient use is absolutely necessary for crisis-free development. Protecting and supporting it is tantamount to contributing to the social fund of future generations, because even life forms that do not seem to benefit man at all can be important in changing living conditions.

Thus, the composition of biological diversity, wild and domestic or cultivated biological species, is the only irreplaceable source of food and many medicines, as well as industrial products. Industrialized countries such as the United States receive about $4 / 5 \%$ of their Gross National Product (GNP) from the use of wild species alone. For less developed countries, this figure may be much higher. The modern commercial importance of cultivated plant species and domesticated animals is high, for example, agricultural products in Uzbekistan account for $45 \%$ of GNP. Especially for less developed countries, while earning a lot of money in this regard is not determined by economic indicators, they are a source of livelihood for nations. For example, in Ghana, for $4 / 3$ of the population, wildlife is the main source of protein consumed, and for almost $80 \%$ of people in developing countries, traditional medicines derived from wild animals and plants are the first major health measures. Even 1/4 of modern pharmacopoeial medicines contain active ingredients of plants that are used, and the undiscovered possibilities in it make up a small fraction of the useful substances.

Biodiversity forms the biosphere, in which, along with other biological species, man lives, and survival and success depend on his condition. In the past, human activity was not so extensive compared to the scale of natural processes. Now the situation is different, and as humanity approaches the 21st century, climate change, desertification, land degradation and other signs show that we are losing our future, both nationally and globally. The Aral Sea crisis, caused by the improper development of the Central Asian region, is a clear example of how dangerous such development can have consequences for both individual regions and the planet as a whole.

In the past, biodiversity conservation was neglected in many countries. However, the level of understanding of the problem facing the world has also increased. Today, the conservation of biodiversity is a global priority and, as such, has become part of the sustainable development plan of nations.

In 1992, 156 countries signed at the UN Conference on Environment and Development the Convention on Biological Diversity is a decisive step in this direction. (High-Level Meeting on Land Issues in Rio de Janeiro) It entered into force in 1993 as an international instrument and was ratified in late 1995 in 120 countries, including Uzbekistan. The main objectives of the Convention:

- The biological resources of the Earth conserving the diversity of plants, animals, and microorganisms, both on land and in water.;

- Ensuring that countries use their biological resources in agriculture, forestry and fisheries in ways that do not harm either the resources or these sectors;

- Encourage the use of genetic resources and the fair and equal distribution of benefits on this basis.

The Convention requires governments to ensure the conservation and efficient use of biodiversity in the management and development of natural 
CURRENT RESEARCH JOURNAL OF HISTORY 2(6): 27-29, June 2021

DOI: https://doi.org/10.37547/history-crjh-02-06-06

ISSN 2767-472X

(C)2021 Master Journals

Crossref doi 8 Google

Accepted 11 th June, 2021 \& Published 16 $6^{\text {th } J u n e, ~} 2021$

resources. It includes an assessment of national economic structures and policies to identify ways to create economic conditions to promote their conservation and efficient use. In addition, Coventia stipulates that its Parties (or States whose legislatures are obliged to bind themselves to this Agreement) must take certain measures, including:

- Development of national strategies for the conservation and sustainable use of biological resources;

- promoting public awareness and education;

- establishment of research and training programs;

- Ensuring the necessary account of biodiversity issues at the stage of economic development through a special process of "environmental impact assessment";

- Encourage scientific and technical cooperation between the parties.

\section{Conclusion}

Conservation of biodiversity should be to ensure the formation of a single general structure of national biological resource management. To do this, it must be reflected and strengthened in the strategy of the industry. Recognizing the importance of biodiversity resources for its sustainable development, Uzbekistan has acceded to the International Convention on Biodiversity. It is limited to the conservation and use of biodiversity.

\section{REFERENCES}

1. Conservation of biological diversity. Tashkent: 1998.

2. Biological protection of plants. Tashkent: 2003.
3. Yormatova D. Botany. Tashkent: 2002.

4. Yuldashev S. Cultivation of plant products. Tashkent: 2003. 